\title{
FLORISTIC COMPOSITION AND SIMILARITY OF A CAATINGA FOREST AREA, BAHIA, BRAZIL
}

\author{
W. C. A. BATISTA ${ }^{1}$, A. DE PAULA ${ }^{2}$, P. A. B. BARRETO-GARCIA ${ }^{3}$, R. S. FONSECA ${ }^{4}$, A. DE O. SOARES FILHO ${ }^{5}$, S. G. M. \\ BATISTA $^{6}$ \\ Universidade Estadual do Sudoeste da Bahia ${ }^{1,2,3,5,6}$, Universidade Federal de Minas Gerais ${ }^{4}$ \\ ORCID ID: https://orcid.org/0000-0003-3676-3846² \\ apaula@uesb.edu.br ${ }^{2}$
}

Submetido $12 / 04 / 2020$ - Aceito $16 / 10 / 2020$

DOI: $10.15628 /$ holos.2020.9900

\section{ABSTRACT}

The present study evaluated floristic composition, similarity and the phytogeographic structuring framework of Caatinga in the Contendas do Sincorá National Forest. The climate of the region is BSwh', with annual precipitation of 500 to $700 \mathrm{~mm}$ and altitude between 300 and $400 \mathrm{~m}$. The soil is eutrophic red-yellow ultisol. Floristic similarity was established by the unweighted pair group method with arithmetic mean. Fifty-one (51) taxa were found distributed in 20 families. The families with the largest number of genera and species were Fabaceae and Euphorbiaceae. The classification for this physiognomy was Forested Savanna-Steppe. Floristic similarity revealed a tendency of grouping between fragments of the same state and ecoregion. Despite the history of exploitation, the floristic composition was as expected for Caatinga areas. The similarity analysis revealed that the area in question does not have a similar floristic identity to the other Caatinga areas analyzed.

\section{COMPOSIÇÃO E SIMILARIDADE FLORÍSTICA DE UMA ÁREA DE CAATINGA ARBÓREA, BAHIA, BRASIL}

\section{RESUMO}

O presente estudo avaliou composição florística, similaridade e o enquadramento fitogeográfico da Caatinga na Floresta Nacional Contendas do Sincorá. O clima da região é BSwh', com precipitação anual de 500 a $700 \mathrm{~mm}$ e altitude entre 300 e $400 \mathrm{~m}$. O solo é Argissolo Vermelho Amarelo Eutrófico. A similaridade florística foi estabelecida por meio do método de ligação de médias não-ponderadas. Foram encontrados 51 táxons distribuídos em 20 famílias. As famílias com maior número de gêneros e espécies foram Fabaceae e Euphorbiaceae. A classificação para esta fisionomia foi
Savana-Estépica Florestada. A similaridade florística revelou uma tendência de agrupamento entre fragmentos do mesmo estado e ecorregião. Apesar do histórico de exploração, a composição florística foi a esperada para áreas de Caatinga. A análise de similaridade revelou que a área em questão não possui identidade florística semelhante às demais áreas de Caatinga analisadas.

PALAVRAS-CHAVE: Complexo da Chapada Diamantina, Depressão Sertaneja Meridional, Savana-Estépica Florestada, semiárido, Floresta Nacional Contendas do Sincorá. 


\section{INTRODUCTION}

Savannas have small or medium-sized trees ( 3 to $10 \mathrm{~m}$ high), generally spaced and with wide, low-spreading crowns (IBGE, 2012). According to the same publication, the term Savanna was coined by Fernández de Oviedo y Valdés, designating Venezuela's tree-lined woodlands, and later introduced by Spanish naturalists on the African continent. The Savanna-Steppe, which has several subgroups, is the name that best defines the Brazilian vegetation types of the northeastern semi-arid regions, known as Caatinga.

According to Velloso et al. (2002), the Caatinga is subdivided into eight ecoregions: the Campo Maior Complex, the Ibiapaba-Araripe Complex, the Sertaneja Setentrional Depression, the Borborema Plateau, the Sertaneja Meridional Depression, the São Francisco Dunes, the Chapada Diamantina Complex and the Raso da Catarina. Each ecoregion has different vegetation characteristics influenced by soil types, water availability, altitude and site relief.

The Caatinga is a unique ecosystem in the world with a significant number of rare and endemic taxa (FERRAZ et al., 2013; PEREIRA JÚNIOR et al., 2014; FERNANDES \& QUEIROZ, 2018) and occupies approximately $10 \%$ of the Brazilian territory (GUERRA et al., 2014).

Despite its uniqueness it is one of the least studied biomes in the country. According to Silva et al. (2015), the Amazon and the Atlantic Forest receive many researchers among the biomes present in the country considering their high riches and international interest in these areas. The Cerrado has a very high number of publications compared to those already mentioned, while the Caatinga has less than $5 \%$ of the number of publications that each of these biomes has. The Chapada Diamantina region and the South region (Mata Atlântica) in Bahia are regions which concentrate the largest number of publications, even though the Caatinga is present in more than half of the state.

The present study was motivated by the existence of this information gap regarding this important Brazilian biome, especially regarding the state of Bahia. Thus, this work aimed to perform a floristic survey, to establish the phytogeographic structuring framework and perform a floristic similarity analysis of a Caatinga tree fragment located in the Contendas do Sincorá National Forest, southwestern Bahia state.

\section{MATERIALS AND METHODS}

The study was carried out at the Contendas do Sincorá National Forest (Flona), situated on the BA-026 highway, km 22, in the municipality of Contendas do Sincorá, with geographic coordinates (UTM) 271468, 8460009 (headquarters), in the southwest of Bahia State (Figure 1). 


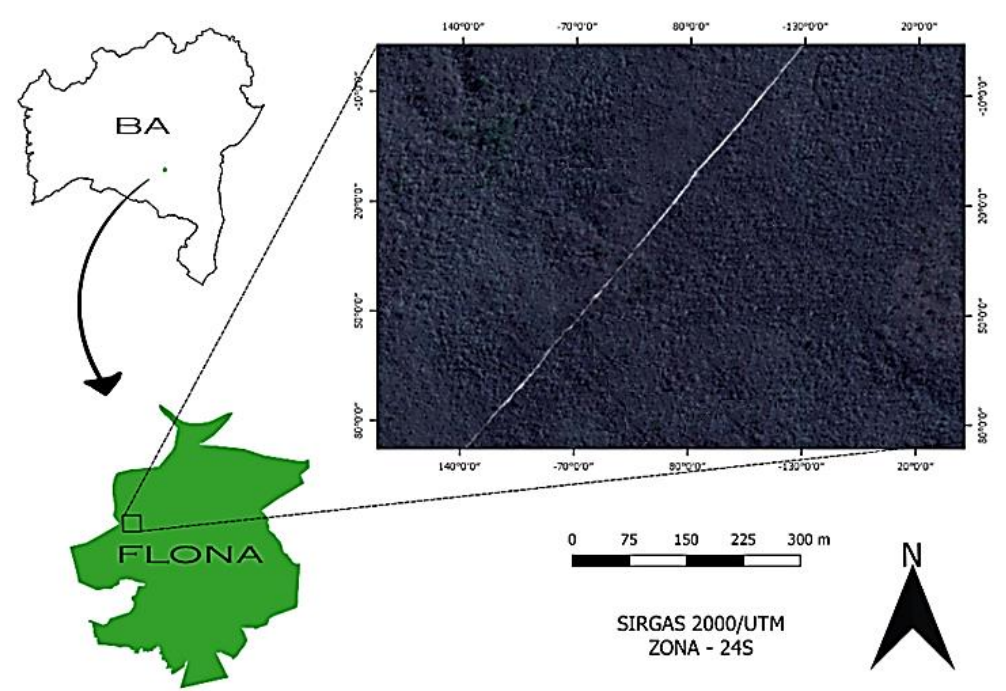

Figure 1: Location map of the study area, Contendas do Sincorá National Forest (Flona), in the municipality of Contendas do Sincorá, Bahia, Brazil. Author: Adriano Castro de Brito.

The Extrema farm was bought by a mining company aiming to extract timber for coal production. As the results were below expectations, it was sold to a second mining company that had the same objective. Once again production was considered low and the farm was ceded to IBAMA in exchange for forest replacement credits in 1997. Flona was officially created by Presidential Decree, without number, of September 21, 1999.

According to MMA (2006), the relief unit is called Peripheral and Interplanaltic Depressions. No major structural deformation was found in the area such as displacement, pushing or even fracture failures. This fact was determinant for the low water availability of its groundwater. The predominant formation in the buffer zone is sandy, which is east of the unit, with an altitude ranging from $300 \mathrm{~m}$ to $400 \mathrm{~m}$ and dominated by siliciclastic and bimodal igneous rocks.

The climate of the region is BSwh' (Köppen Classification), warm, semi-arid, with annual precipitation of 500 to $700 \mathrm{~mm}$. The rainy season occurs between November and January, with an average temperature of $23^{\circ} \mathrm{C}$ and a relative humidity of 60 to $80 \%$ (LIMA \& LIMA, 1999).

The soil is eutrophic red-yellow ultisol (MMA, 2006). Soil chemical and physical analyzes were performed at the UESB Soil Chemistry Laboratory. The collection was performed at a depth of 0 to $10 \mathrm{~cm}$, disregarding the litter. The textural class found was loam. The values found were: $\mathrm{pH}(\mathrm{H} 2 \mathrm{O})=6.5 ; \mathrm{P}=3 \mathrm{mg} / \mathrm{dm}^{3} ; \mathrm{K}+=0.2 \mathrm{c} \mathrm{molc} \mathrm{dm}^{3} ; \mathrm{Ca}_{2}+=4.3 \mathrm{c} \mathrm{molc} \mathrm{dm}{ }^{3} ; \mathrm{Mg}_{2}+1.7 \mathrm{c} \mathrm{molc} \mathrm{dm}{ }^{3}$ and $\mathrm{Al}_{3}+0 \mathrm{c} \mathrm{molc} \mathrm{dm} 3 ; \mathrm{H}+=1.6 ;$ Clay $=190 ;$ Sand $=410$ and Silt $=410$.

Flona is inserted in the Chapada Diamantina Complex ecoregion, with part of the Sertaneja Meridional Depression (VELLOSO et al., 2002). The vegetation is predominantly Caatinga forest, with Cerrado and dry forest species. It is an ecotone between the Cerrado, Caatinga and Atlantic forest biomes, with difficult delimitation due to their interpenetration (LIMA \& LIMA, 1999).

The floristic composition was obtained through a phytosociological survey that covered an area of $10,400 \mathrm{~m}^{2}$, in addition to eventual fertile material collections. Only individuals of tree size 
with a diameter at breast height equal to or greater than $5 \mathrm{~cm}$ were sampled. This inclusion criterion aimed to restrict the research to individuals of arboreal size, since the objective was to analised the potential use for the caatinga area in question, in order to propose sustainable uses of the resource. Identification of the collected material was performed by consulting the specialized bibliography (Flora Brasiliensis, Flora from Bahia, Flora from Sergipe, Flora Neotropica, QUEIROZ, 2009, among others) and comparing it with specimens from the UESB herbarium in Vitória da Conquista (HUESBVC). The classification of botanical families was performed following the system APG IV (2016).

Floristic similarity relationships were performed between the study area and 19 other surveys in Caatinga (Savana-Steppe) from different states (Table 1). It is noteworthy that, for this analysis, only tree size species were used.

Table 1: List of articles used for floristic similarity assessment, with their respective locations, sampling methods and ecoregion.

\begin{tabular}{|c|c|c|c|}
\hline Author & Location & Sampling & Ecoregion \\
\hline Costa et al. (2015) & Tucano (BA) & Random collections & SMD and RC \\
\hline Farias \& Castro (2004) & Campo Maior (PI) & 200 quadrant points & CMC \\
\hline Ferraz et al. (2013) & $\begin{array}{l}\text { Monumento Natural Grota do } \\
\text { Angico (SE) }\end{array}$ & 30 lots $(20 \times 20 \mathrm{~m})$ & SMD \\
\hline Guerra et al. (2014) & Apodi (RN) & 24 lots $(10 \times 20 \mathrm{~m})$ & SMD \\
\hline $\begin{array}{l}\text { Lemos \& } \quad \text { Meguro } \\
(2015)\end{array}$ & $\begin{array}{l}\text { Estação Ecológica de Aiuaba } \\
\text { (CE) }\end{array}$ & 50 lots $(10 \times 10 \mathrm{~m})$ & IAC \\
\hline Lemos \& Rodal (2002) & $\begin{array}{l}\text { Parque Nacional Serra da } \\
\text { Capivara (PI) }\end{array}$ & 50 lots $(10 \times 20 \mathrm{~m})$ & CMC \\
\hline Lemos \& Zappi (2012) & $\begin{array}{l}\text { Estação Ecológica de Aiuaba } \\
\text { (CE) }\end{array}$ & Random collections & IAC \\
\hline Lemos (2004) & $\begin{array}{l}\text { Parque Nacional Serra da } \\
\text { Capivara (PI) }\end{array}$ & $\begin{array}{l}\text { Herbarium and random } \\
\text { collections }\end{array}$ & $\mathrm{CMC}$ \\
\hline Lima \& Lima (1999) & Contendas do Sincorá (BA) & 100 lots $(20 \times 5 \mathrm{~m})$ & SMD \\
\hline Oliveira et al. (2009) & Serra do Cariri (PB) & 40 lots $(50 \times 4 \mathrm{~m})$ & SMD \\
\hline $\begin{array}{l}\text { Pereira Júnior et al. } \\
\text { (2012) }\end{array}$ & Monteiro (PB) & 100 lots $(10 \times 10 \mathrm{~m})$ & SMD \\
\hline Pinheiro et al. (2010) & Mirandiba (PE) & 60 lots $(10 \times 10 \mathrm{~m})$ & SMD \\
\hline Pinheiro et al. (2010) & Mirandiba (PE) & 60 lots $(10 \times 10 \mathrm{~m})$ & SMD \\
\hline Pinheiro et al. (2010) & Mirandiba (PE) & 60 lots $(10 \times 10 \mathrm{~m})$ & SMD \\
\hline Rodal et al. (2008) & Custódia e Floresta (PE) & 50 lots $(10 \times 10 \mathrm{~m})$ & SMD \\
\hline Sabino et al. (2016) & Patos (PB) & 50 lots $(20 \times 20 \mathrm{~m})$ & SMD \\
\hline Sanquetta et al. (2014) & Brumado (BA) & 17 lots $(10 \times 25 \mathrm{~m})$ & SMD \\
\hline Santos et al. (2007) & Juvenília (MG) & Random collections & SMD \\
\hline Santos et al. (2007) & Montalvânia (MG) & Random collections & SMD \\
\hline
\end{tabular}

In which: BA - Bahia, CE - Ceará, MG - Minas Gerais, PB - Paraíba, PE - Pernambuco, PI - Piauí, RN - Rio Grande do Norte, SE - Sergipe, CDC - Chapada Diamantina Complex, CMC - Campo Maior Complex, IAC - IbiapabaAraripe Complex, SMD - Sertaneja Meridional Depression and RC - Raso da Catarina. 
Climate, soil type, altitude and rainfall characteristics were also evaluated (Table 2).

Table 2: List of articles used for floristic similarity assessment, with their respective soil types, climate (Köppen classification), altitude and precipitation.

\begin{tabular}{lccccc}
\hline \multicolumn{1}{c}{ Author } & Group & Soil type & Climate & Altitude & Annual precipitation \\
\hline Costa et al. (2015) & 3 & $\mathrm{Pl}$ & $\mathrm{Aw}$ & $650 \mathrm{~m}$ & $512.2 \mathrm{~mm}$ \\
Costa et al. (2015) & 3 & LN & Aw & $650 \mathrm{~m}$ & $512.2 \mathrm{~mm}$ \\
Farias \& Castro (2004) & 2 & La & C1WA'4a' & 95 to $120 \mathrm{~m}$ & $1,305 \mathrm{~mm}$ \\
Ferraz et al. (2013) & 3 & Nand PI & BSh & $160 \mathrm{~m}$ & $600 \mathrm{~mm}$ \\
Guerra et al. (2014) & 4 & Ca & BSWh' & $71 \mathrm{~m}$ & $767 \mathrm{~mm}$ \\
Lemos \& Meguro (2015) & 2 & RYU & BShw' & 560 to $600 \mathrm{~m}$ & $582 \mathrm{~mm}$ \\
Lemos \& Rodal (2002) & 2 & RYU & BSwh' & $600 \mathrm{~m}$ & $689 \mathrm{~mm}$ \\
Lemos \& Zappi (2012) & 2 & RYU & BShw' & $560 \mathrm{~m}$ & $474 \mathrm{~mm}$ \\
Lemos (2004) & 2 & RYU & BSh & 500 to $600 \mathrm{~m}$ & $687.8 \mathrm{~mm}$ \\
Lima \& Lima (1999) & 1 & RYU & BSwh' & 295 to $380 \mathrm{~m}$ & $596 \mathrm{~mm}$ \\
Oliveira et al. (2009) & 4 & V & Bsh & $407 \mathrm{~m}$ & $500 \mathrm{~mm}$ \\
Pereira Júnior et al. (2012) & 4 & Lu & Bsh & $600 \mathrm{~m}$ & $431,8 \mathrm{~mm}$ \\
Pinheiro et al. (2010) & 1 & U & Aw & 436 to $572 \mathrm{~m}$ & $431.8 \mathrm{~mm}$ \\
Pinheiro et al. (2010) & 3 & QN & Aw & 436 to $572 \mathrm{~m}$ & $431.8 \mathrm{~mm}$ \\
Pinheiro et al. (2010) & 3 & LN & Aw & 436 to $572 \mathrm{~m}$ & $431.8 \mathrm{~mm}$ \\
Pinheiro et al. (2010) & 4 & Lu & Aw & 436 to $572 \mathrm{~m}$ & $431.8 \mathrm{~mm}$ \\
Rodal et al. (2008) & 3 & $\mathrm{~N}$ and PI & Aw & 550 and $450 \mathrm{~m}$ & $632 \mathrm{and} 651 \mathrm{~mm}$ \\
Sabino et al. (2016) & 4 & Lu & Bsh & $280 \mathrm{~m}$ & $800 \mathrm{~mm}$ \\
Sanquetta et al. (2014) & 4 & Ca & BSh & $457 \mathrm{~m}$ & $640 \mathrm{~mm}$ \\
Santos et al. (2007) & 1 & $U$ & Aw & $445 \mathrm{~m}$ & $868 \mathrm{~mm}$ \\
Santos et al. (2007) & 1 & U & Aw & $495 \mathrm{~m}$ & $910 \mathrm{~mm}$ \\
\hline
\end{tabular}

In which: U - Ultisol, RYU - Red-Yellow Ultisol, Ca - Cambisol, La - Latosol, Lu - Luvisol, N - Neosol, QN - Quartzeneic Neosols, LN - Litholic Neosol, PI - Planossol and V - Vertisol.

The unweighted pair group method with arithmetic mean (UPGMA) and the Bray-Curtis similarity coefficient (1957) were used. Only individuals classified at species level were considered. The calculations were performed using Fitopac 2.1 software (SHEPHERD, 2010). The cut-off line for group identification was performed using the methodology proposed by Mojena (1977). Milligan \& Cooper (1985) suggested the value of 1.25 for the constant "Ф".

\section{RESULTS AND DISCUSSION}

We sampled 51 morphospecies distributed in 20 families (Table 3). The families with the highest genera and species richness were Fabaceae and Euphorbiaceae. Several surveys conducted in Caatinga pointed out these families as being of great importance (CARDOSO et al., 2009; PINHEIRO et al., 2010; AMARAL et al., 2012; FERREIRA et al., 2013; APGAUA et al., 2014; LEITÃO et al., 2014; LEITE et al., 2015; LEMOS \& MEGURRO, 2015; SABINO et al., 2016). 
Table 3: Families and species sampled in Contendas do Sincorá National Forest, Contendas do Sincorá Municipality, Bahia, where: $\mathrm{CN}$ = common name; VN = voucher number at the Herbarium of the State University of Southwest Bahia - Vitória da Conquista (HUESBVC).

\begin{tabular}{|c|c|c|c|}
\hline Familie & Species & $\mathrm{CN}$ & VN \\
\hline \multirow[t]{4}{*}{ Anacardiaceae } & Astronium fraxinifolium Schott & gonçalo-alves & 9299 \\
\hline & Astronium urundeuva (M. Allemão) Engl. & aroeira & \\
\hline & Schinopsis brasiliensis Engl. & baraúna & 9302 \\
\hline & Spondias tuberosa Arruda & umbuzeiro & 9301 \\
\hline \multirow[t]{2}{*}{ Annonaceae } & Annona coriacea Mart. & araticum & \\
\hline & Annona vepretorum Mart. & $\begin{array}{l}\text { araticum-da- } \\
\text { bahia }\end{array}$ & 9323 \\
\hline Apocynaceae & Aspidosperma pyrifolium Mart. \& Zucc. & pereiro & 9300 \\
\hline \multirow[t]{2}{*}{ Araliaceae } & Aralia bahiana J. Wen & & 9297 \\
\hline & Aralia warmingiana (Marchal) J.Wen & & \\
\hline Arecaceae & Syagrus coronata (Mart.) Becc. & licuri & \\
\hline \multirow[t]{3}{*}{ Bignoniaceae } & Handroanthus selachidentatus (A.H. Gentry) S. Grose & & 9309 \\
\hline & Tabebuia roseoalba (Ridl.) Sandwith & ipê-branco & \\
\hline & Tabebuia sp. & & \\
\hline \multirow[t]{3}{*}{ Boraginaceae } & Cordia americana (L.) Gottschling \& J.S.Mill. & guaiuvira & \\
\hline & Cordia incognita Gottschling \& J.S.Mill. & casca-fina & 9305 \\
\hline & Cordia trichotoma (Vell.) Arráb. ex Steud. & freijó & \\
\hline Burseraceae & Commiphora leptophloeos (Mart.) J.B. Gillett & $\begin{array}{l}\text { amburana-de- } \\
\text { cambão }\end{array}$ & 9316 \\
\hline Cactaceae & Quiabentia zehntneri (Britton \& Rose) Britton \& Rose & quiabento & 9298 \\
\hline Celastraceae & Monteverdia rigida (Mart.) Biral & pau-de-colher & \\
\hline \multirow[t]{2}{*}{ Combretaceae } & Combretum monetaria Mart. & mofumbo & 9304 \\
\hline & Terminalia eichleriana Alwan \& Stace & pau-de-chapada & 9315 \\
\hline \multirow[t]{8}{*}{ Euphorbiaceae } & Cnidoscolus urens (L.) Arthur & cansanção & 9328 \\
\hline & Croton floribundus Spreng. & velame & 9313 \\
\hline & Croton piptocalyx Müll. Arg. & caixeta & 9325 \\
\hline & Jatropha mollissima (Pohl) Baill. & pinhão-bravo & 9311 \\
\hline & Manihot carthagenensis (Jacq.) Müll.Arg. & & 9317 \\
\hline & Maprounea guianensis Aubl. & $\begin{array}{l}\text { marmeleiro-do- } \\
\text { campo }\end{array}$ & 9320 \\
\hline & Sapium glandulosum (L.) Morong & leitteiro & 9312 \\
\hline & Sebastiania brasiliensis Spreng. & mata-berne & 9326 \\
\hline \multirow[t]{6}{*}{ Fabaceae } & Chloroleucon foliolosum (Benth.) G.P. Lewis & arapiraca & 9308 \\
\hline & Coursetia rostrata Benth. & viuvinha & 9310 \\
\hline & Dalbergia miscolobium Benth. & sapuvussu & \\
\hline & Leucochloron limae Barneby \& J.W.Grimes & couvi & 9318 \\
\hline & Mimosa ophthalmocentra Mart. ex Benth. & jurema-embira & 9324 \\
\hline & Mimosa tenuiflora (Willd.) Poir. & jurema-preta & 9322 \\
\hline
\end{tabular}




\begin{tabular}{|c|c|c|c|}
\hline & \multicolumn{3}{|l|}{ Mimosa sp.1 } \\
\hline & \multicolumn{3}{|l|}{ Mimosa sp.2 } \\
\hline & Peltogyne pauciflora Benth. & $\begin{array}{l}\text { coração-de- } \\
\text { negro }\end{array}$ & 9307 \\
\hline & Pityrocarpa moniliformis (Benth.) Luckow \& R.W.Jobson & quipé & \\
\hline & Pseudopiptadenia contorta (DC.) G.P.Lewis \& M.P.Lima & angico-rosa & 9306 \\
\hline & Senegalia piauhiensis (Benth.) Seigler \& Ebinger & jurema-branca & 9314 \\
\hline & Senegalia velutina (DC.) Seigler \& Ebinger & & 9321 \\
\hline \multirow[t]{2}{*}{ Malvaceae } & Ceiba boliviana Britten \& Baker $\mathrm{f}$. & barriguda & \\
\hline & Pseudobombax simplicifolium A. Robyns & imburuçu & 9319 \\
\hline Myrtaceae & Campomanesia sessiliflora (O. Berg) Mattos & $\begin{array}{l}\text { guabiroba- } \\
\text { verde }\end{array}$ & 9327 \\
\hline Moraceae & Ficus sp. & & \\
\hline Nyctaginaceae & Guapira opposita (Vell.) Reitz & maria-faceira & 9303 \\
\hline Polygonaceae & Coccoloba alnifolia Casar. & & \\
\hline Rutaceae & Esenbeckia febrifuga (A. St.-Hil.) A. Juss. ex Mart. & mamoninha & 9296 \\
\hline Sapindaceae & $\begin{array}{l}\text { Allophylus quercifolius (Mart.) Radlk. } \\
\text { Dilodendron bipinnatum Radlk. }\end{array}$ & $\begin{array}{l}\text { estraladão } \\
\text { maria-pobre }\end{array}$ & \\
\hline
\end{tabular}

Only six species were present in the study by Lima \& Lima (1999) in the same area (Astronium urundeuva, Jatropha molissima, Monteverdia rigida, Pseudobombax simplicifolium, Schinopsis brasiliensis and Spondias tuberosa). This indicates a major change in Flona's floristic composition since the last survey in the area.

The survey also showed that $37 \%$ of the sampled morphospecies are exclusive to Flona when compared to the articles used in the similarity study (Table 1): Annona coriacea, Aralia bahiana, Aralia warmingiana, Ceiba boliviana, Cnidoscolus urens, Coccoloba alnifolia, Cordia americana, Coursetia rostrata, Croton floribundus, Croton piptocalyx, Dalbergia miscolobium, Esenbeckia febrifuga, Handroanthus selachidentatus, Pseudopiptadenia contorta, Quiabentia zehntneri, Sapium glandulosum, Senegalia velutina and Terminalia eichleriana.

Some species such as Aspidosperma pyrifolium, Astronium urundeuva, Commiphora leptophloeos, Mimosa ophthalmocentra, Mimosa tenuiflora and Schinopsis brasiliensis were reported as important in other studies in Caatinga (APGAUA et al., 2014; FERRAZ et al., 2014; SILVA et al., 2014; LEITE et al., 2015; SABINO et al., 2016).

It is important to highlight that the presence of $A$. pyrifolium is mainly due to its adaptability to the environment. It occurs in northeastern Brazil and northern Minas Gerais, ranging from shrubbery in dry caatinga areas, to arboreal in forest caatinga. The species adapts well to locations with long drought and stony shallow soils (SILVA et al., 2014) and usually occurs at altitudes below $332 \mathrm{~m}$ (LEITE et al., 2015), constituting similar characteristics to the area of this survey.

Leite et al. (2015) listed M. ophthalmocentra and M. tenuiflora as pioneers, occurring in previously degraded regions and in the middle regeneration stage. The area importantly 
underwent periods of vegetation exploitation before being transformed into Flona, which corroborates the information of the authors mentioned above.

According to Ferraz et al. (2014), the good adaptation of $A$. urundeuva to an area is an indication that early species (with greater dispersal and establishment capacity) are giving way to those with higher competitive capacity. This fact demonstrates that the area is regenerating from the impact suffered during the wood extraction for coal production.

The Burseraceae family presented only the C. leptophloeos species. This was also recorded by Lemos \& Meguro (2015) in the state of Ceará, in a tree stratum with individuals higher than five meters. Guerra et al. (2014) found the species in an anthropized area in Rio Grande do Norte. According to Sanquetta et al. (2014), the species showed a high adaptability to both soil and water deficit in a study conducted in Brumado (BA), which is characteristic of the region.

It is worth mentioning the presence of $H$. selachidentatus and Leucochloron limae which were classified as "almost threatened" on the endangered species red list (MMA 2014) and Syagrus coronata and S. tuberosa, immune to cutting (State Law 13908, 2018).

The physiognomic classification that best fit the study area was Forested Savanna-Steppe (IBGE, 2012), due to its floristic composition (Table 3) and its structure. This subgroup is highlighted by $S$. tuberosa, C. leptophloeos and A. pyrifolium, as well as others of the Mimosa genus. Its structure is formed by two strata: one superior and sparse arboreal, and the other inferior grassywoody, with relevant phytophysiognomic importance.

Six groups were found regarding floristic similarity (Figure 2). The cut-off line for group formation was 0.88 . There was a tendency to cluster between studies in the same state. The exceptions were Farias \& Castro (2004) in the municipality of Campo Maior (PI), Lima \& Lima (1999) and present study in Contendas do Sincorá (BA) and Sanquetta et al. (2014) in Brumado (BA). The survey carried out by Farias \& Castro (2004) in the municipality of Campo Maior (PI) presents very different soil type, climate, altitude and annual precipitation from the Serra da Capivara National Park (LEMOS, 2004; LEMOS \& RODAL, 2002), as can be observed in Table 2. It is noteworthy that the work by Lima \& Lima (1999) carried out in Contendas do Sincorá (BA) was conducted in 1990. The wood exploitation history in the area until 1997 (the year it was assigned to IBAMA) may be the explanation for the low similarity with the present study. 


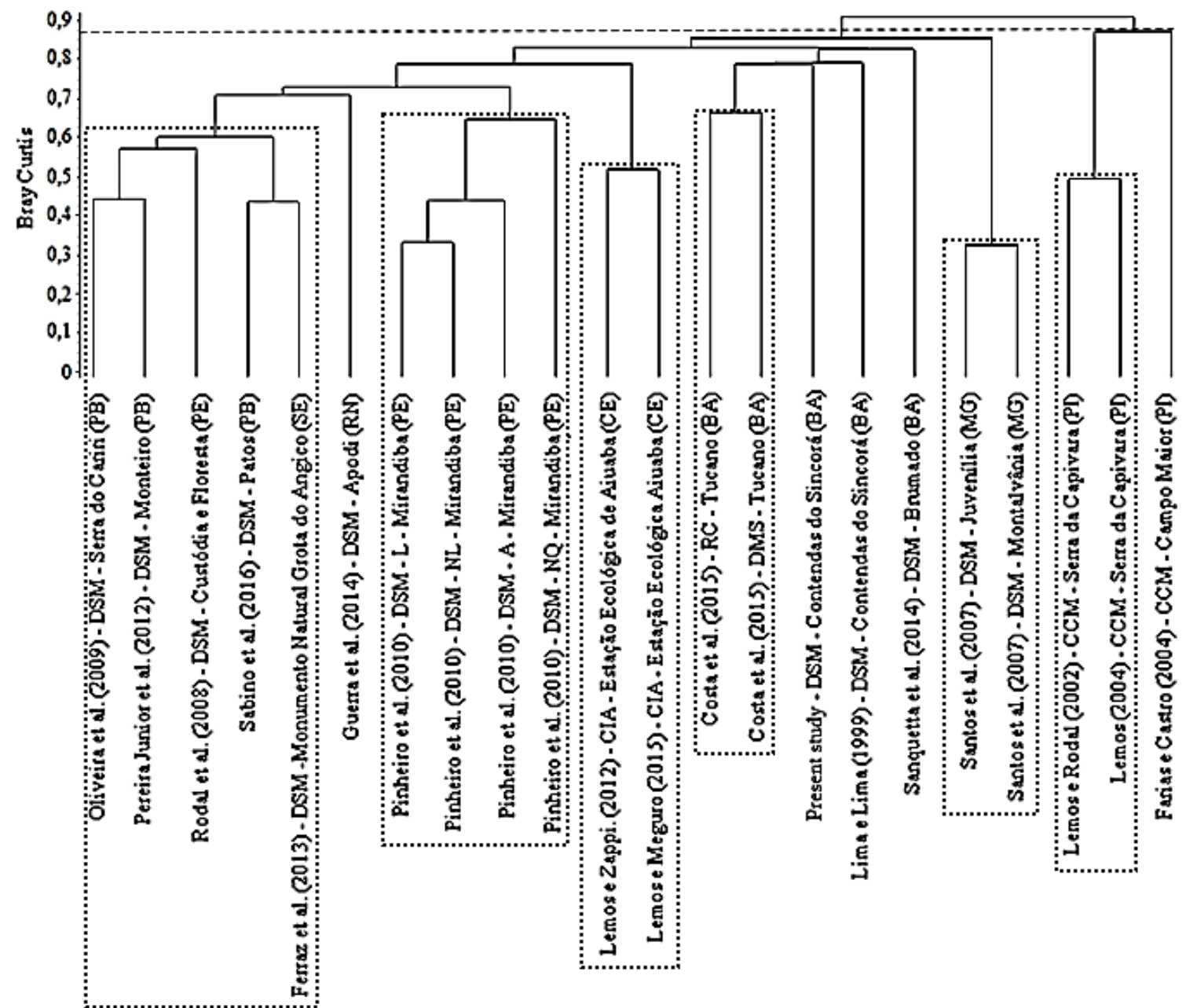

Figure 2: Floristic similarity between Caatinga forest fragments in different states, where: cut-off line for groups (---) and group delimitation (...).

It was found that five of the six created groups exclusively unite an ecoregion: the first, the second and the fifth united the experiments carried out in the Sertaneja Meridional Depression, the third in the Ibiapaba-Araripe Complex, and the sixth in the Campo Maior Complex. The fourth group brought together the Raso da Catarina and Sertaneja Meridional Depression, all in the state of Bahia. In this case, the similar altitude and precipitation found in the surveys were determinant.

The minimum distance found was 0.33 between surveys conducted in the municipalities of Juvenília and Montalvânia, Minas Gerais (SANTOS et al., 2007) (Figure 2). The work carried out in Contendas do Sincorá-BA (LIMA \& LIMA, 1999), did not form a group with the present study, although they were performed in the same area (Figure 1). This indicates that the area no longer had its original characteristics soon after the wood extraction for charcoal production (when the first study was carried out), since it is still in its middle regeneration stage about 20 years after the exploitation.

The cophenetic correlation was 0.85 , indicating that the data provided by the dendrogram were well representative. According to Shepherd (2010), values below 0.7 indicate that the representation of the dendrogram was not satisfactory. 


\section{CONCLUSION}

Despite the exploitation history, floristic composition was expected for Caatinga areas. Due to its floristic composition and physiognomic structure, the physiognomic classification for this physiognomy was Forested Savanna-Steppe.

The similarity analysis revealed that the Contendas do Sincorá National Forest does not have a similar floristic identity to the other Caatinga areas analyzed, including those of Bahia.

\section{ACKNOWLEDGEMENTS}

The present authors would like to express their thanks to Contendas do Sincorá National Forest for the authorization to perform this study.

\section{REFERENCES}

Amaral, G. C., Alves, A. R., Oliveira, T. M., Almeida, K. N. S., Farias, S. G. G., \& Botrel, R. T. (2012). Estudo florístico e fitossociológico em uma área de transição Cerrado-Caatinga no município de Batalha-PI. Scientia Plena, 8(4 (b)), 1-5.

APG, The Angiosperm Phylogeny Group. 2016. (2016). An update of the Angiosperm Phylogeny Group classification for the orders and families of flowering plants: APG IV. Botanical Journal of the Linnean Society, 181(1), 1-20.

Apgaua, D. M. G., Coelho, P. A., Santos, R. M. D., Santos, P. F., \& Oliveira-Filho, A. T. D. (2014). Tree community structure in a seasonally dry tropical forest remnant, Brazil. Cerne, 20(2), 173-182.

Cardoso, D. B. O. S., França, F., Novais, J. S. D., Ferreira, M. H. D. S., Santos, R. M. D., Carneiro, V. M. S., \& Gonçalves, J. M. (2009). Composição florística e análise fitogeográfica de uma floresta semidecídua na Bahia, Brasil. Rodriguésia, 60(4), 1055-1076.

Costa, G. M. D., Cardoso, D., Queiroz, L. P. D., \& Conceição, A. A. (2015). Variações locais na riqueza florística em duas ecorregiões de caatinga. Rodriguésia, 66(3), 685-709.

Farias, R. R. S. D., \& Castro, A. A. J. F. (2004). Fitossociologia de trechos da vegetação do complexo de Campo Maior, Campo Maior, PI, Brasil. Acta Botanica Brasilica, 18(4), 949-963.

Fernandes, M. F., \& Queiroz, L. P. D. (2018). Vegetação e flora da Caatinga. Ciência e Cultura, 70(4), 51-56. 
Ferraz, J. S. F., Ferreira, R. L. C., Silva, J. A. A., Meunier, I. M. J., \& Santos, M. V. F. (2014). Estrutura do componente arbustivo-arbóreo da vegetaçãoem duas áreas de caatinga, no município de Floresta, Pernambuco. Revista Árvore, 38(6), 1055-1064.

Ferraz, R. C., Mello, A. A., Ferreira, R. A., \& Prata, A. P. D. N. (2013). Levantamento fitossociológico em área de Caatinga no monumento natural Grota do Angico, Sergipe, Brasil. Revista Caatinga, 26(3), 89-98.

Ferreira, E. V. R., Prata, A. P. D. N., \& Mello, A. A. D. (2013). Floristic List from a Caatinga Remnant in Poço Verde, Sergipe, Brazil. Check list 96: 1354-1360.

Guerra, A. M. N., Pessoa, M. D. F., \& Maracajá, P. B. (2014). Estudo fitossociológico em dois ambientes da caatinga localizada no assentamento Moacir Lucena, Apodi-RN-Brasil. Revista Verde, 9(1), 141-150.

IBGE, Instituto Brasileiro de Geografia e Estatística. (2012). Manuais técnicos em geociências 1 Manual Técnico da Vegetação Brasileira. 2a ed. Ministério do Planejamento, Orçamento e Gestão e Instituto Brasileiro de Geografia e Estatística Diretoria de Geociências Coordenação de Recursos Naturais e Estudos Ambientais, 271 p.

Leitão, A. C., Vasconcelos, W. A., Cavalcante, A. D. M. B., TINÔCO, L. B. D. M., \& FRAGA, V. D. S. (2014). Florística e estrutura de um ambiente transicional caatinga-mata atlântica. Revista Caatinga, 27(3), 200-210.

Leite, J. A. N., Araujo, L. V. C., Arriel, E. F., Chaves, L. F. C., \& Nobrega, A. M. F. (2015). Análise quantitativa da vegetação lenhosa da Caatinga em Teixeira, PB. Pesquisa Florestal Brasileira, 35(82), 89-100.

Lemos, J. R., \& Meguro, M. (2015). Estudo fitossociológico de uma área de Caatinga na Estação Ecológica (ESEC) de Aiuaba, Ceará, Brasil. Biotemas, 28(2), 39-50.

Lemos, J. R., \& Rodal, M. J. N. (2002). Fitossociologia do componente lenhoso de um trecho da vegetação de caatinga no Parque Nacional Serra da Capivara, Piauí, Brasil. Acta Botanica Brasilica, 16(1), 23-42.

Lemos, J. R., \& Zappi, D. C. (2012). Distribuição geográfica mundial de plantas lenhosas da Estação Ecológica de Aiuaba, Ceará, Brasil. Revista Brasileira de Biociências, 10(4), 446-456.

Lemos, J. R. (2004). Composição florística do Parque Nacional Serra da Capivara, Piauí, Brasil. Rodriguésia, 55-66.

Lima, P. C. F., \& Lima, J. L. S. (1999). Composição florística e fitossociologia de uma área de Caatinga em Contendas do Sincorá, Bahia, microrregião homogênea da Chapada Diamantina. Acta Botanica Brasilica, 123: 441-450.

Milligan, G. W., \& Cooper, M. C. (1985). An examination of procedures for determining the number of clusters in a data set. Psychometrika, 50(2), 159-179. 
MMA, Ministério do Meio Ambiente. (2006). Plano de manejo da Floresta Nacional Contendas do Sincorá - volume I. Instituto Brasileiro de Meio Ambiente e dos Recursos Naturais Renováveis, $132 \mathrm{p}$.

MMA, Ministério do Meio Ambiente. (2014). Lista nacional oficial de espécies da flora ameaçadas de extinção. Portaria MMA 443, 17 de dezembro de 2014.

Mojena, R. (1977). Hierarchical grouping methods and stopping rules: an evaluation. The Computer Journal, 20(4), 359-363.

Oliveira, P. T. B., Trovão, D. M. D. B. M., de Carvalho, E. C. D., Souza, B. C., \& Ferreira, L. M. R. (2009). Florística e fitossociologia de quatro remanescentes vegetacionais em áreas de serra no cariri paraibano. Revista Caatinga, 22(4), 169-178.

Pereira Júnior, L., Andrade, A. P., \& Araújo, K. D. (2012). Composição florística e fitossociológica de um fragmento de caatinga em Monteiro, PB. Holos, 6, 73-87.

Pereira Júnior, L. R., Andrade, A. P. D., Araújo, K. D., Barbosa, A. D. S., \& Barbosa, F. M. (2014). Espécies da caatinga como alternativa para o desenvolvimento de novos fitofármacos. Floresta e Ambiente, 21(4), 509-520.

Pinheiro, K., Rodal, M. J. N., \& Alves, M. (2010). Floristic composition of different soil types in a semi-arid region of Brazil. Revista Caatinga, 232, 68-77.

Queiroz, L. P. D. (2009). Leguminosas da caatinga. Universidad Estadual de Feira de Santana.

Rodal, M. J. N., Martins, F. R., \& Sampaio, E. V. D. S. B. (2008). Levantamento quantitativo das plantas lenhosas em trechos de vegetação de caatinga em Pernambuco. Revista Caatinga, 21(3), 192-205.

Sabino, F. G. D. S., Cunha, M. D. C. L., \& Santana, G. M. (2016). Estrutura da vegetação em dois fragmentos de caatinga antropizada na Paraíba. Floresta e Ambiente, 23(4), 487-497.

Sanquetta, M. N. I., Corte, A. P. D., Sanquetta, C. R., Rodrigues, A. L., \& Mongon, F. (2014). Diversidade e estrutura fitossociológica da caatinga na região de Brumado-BA. Enciclopédia Biosfera, 10(17), 2157-2167.

Santos, R. M. D., Vieira, F. D. A., Fagundes, M., Nunes, Y. R. F., \& Gusmão, E. (2007). Riqueza e similaridade florística de oito remanescentes florestais no norte de Minas Gerais, Brasil. Revista Árvore, 31(1), 135-144.

Shepherd, G. J. (2010). Fitopac - manual do usuário. Universidade Estadual de Campinas, 6 p.

Silva, J. G., Paula, A., Paula, R. C. A. L., Barreto, P. A. B., Tagliaferre, C. (2015). Análise cienciométrica em botânica e ecologia no estado da Bahia. Sodebras, 10(117), 159-163.

Silva, N., Lucena, R. F. P., Farias Lima, J. R., Lima, G. D. S., Carvalho, T. K. N., Sousa Júnior, S. P., \& Alves, C. A. B. (2014). Conhecimento e Uso da Vegetação Nativa da Caatinga em uma 
Comunidade Rural da Paraíba, Nordeste do Brasil. Boletim do Museu de Biologia Mello Leitão, 34, 5-37.

Velloso, A. L., Sampaio, E. V. S. B., \& Pareyn, F. G. C. (2002). Ecorregioes propostas para o Bioma caatinga. Recife: Associaçao Plantas do Nordeste, Instituto de Conservaçao Ambiental. The Nature Conservancy do Brasil, 76 p.

\section{COMO CITAR ESTE ARTIGO:}

Batista, W. C. A., Paula, A. De, Barreto-Garcia, P. A. B., Fonseca, R. S., Soares Filho, A. De O., Batista, S. G. M. (2020). Floristic composition and similarity of a Caatinga forest area, Bahia, Brazil. Holos 36(6), 1-14.

\section{SOBRE OS AUTORES}

\section{W. C. A. BATISTA}

Mestre em Ciências Florestais. Engenheiro Florestal. E-mail: willyanbatista@yahoo.com.br ORCID ID: https://orcid.org/0000-0002-9745-0192

\section{A. DE PAULA}

Engenheiro Florestal. Doutor. em Ecologia e Recursos Naturais pela Universidade Federal de São Carlos. Departamento de Engenharia Agrícola e Solos. Ciências Florestais. E-mail: apaula@uesb.edu.br ORCID ID: https://orcid.org/0000-0003-3676-3846

\section{P. A. B. BARRETO-GARCIA}

Engenheira Florestal. Doutora em Produção Vegetal pela Universidade Estadual do Norte Fluminense Departamento de Engenharia Agrícola e Solos. Ciências Florestais. E-mail: patriciabarreto@uesb.edu.br ORCID ID: https://orcid.org/0000-0002-8559-2927

\section{R. S. FONSECA}

Bióloga. Doutora em Botânica pela Universidade Federal de Viçosa. Instituto de Ciências Agrárias Dendrologia e Sistemática Vegetal.E-mail: rubiafonseca@ hotmail.com

ORCID ID: https://orcid.org/0000-0001-7257-874X

\section{A. DE O. SOARES FILHO}

Biólogo. Doutor em Botânica pela Universidade Estadual de Feira de Santana. Departamento de Ciências Naturais. Ecologia. E-mail: avaldo.oliveira@uesb.edu.br

ORCID ID: $\underline{\text { https://orcid.org/0000-0003-1574-2368 }}$

\section{S. G. M. BATISTA}

Mestre em Ciências Florestais. Engenheira Florestal. E-mail: suellenmonteiro04@ gmail.com ORCID ID: http://orcid.org/0000-0002-6160-7338

Editor(a) Responsável: Anísia Galvão

Pareceristas Ad Hoc: CRISTIAN ZERWES E SÔNIA MARIA ALBERTINO 


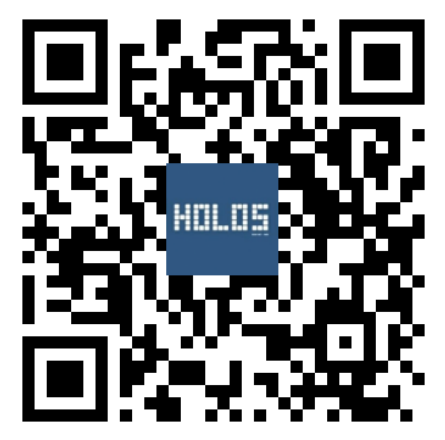

